\title{
Does Sexual Behavior Cause Complaints on Sexually Transmitted Infections in Female Sex Workers in the Work Area of the Community Health Center of Pedan?
}

\author{
$1^{\text {st }}$ Lilik Hartati \\ Program Studi DIII Kebidanan \\ Sekolah Tinggi Ilmu Kesehatan \\ Muhammadiyah Klaten \\ Jl. Ir. Soekarno Km.1, Buntalan, Klaten \\ Tengah, Klaten, Jawa Tengah \\ hartatililik91@gmail.com \\ $4^{\text {th }}$ Dina Erfiana \\ Program Studi DIII Kebidanan \\ Sekolah Tinggi Ilmu Kesehatan \\ Muhammadiyah Klaten \\ Jl. Ir. Soekarno Km.1, Buntalan, Klaten \\ Tengah, Klaten, Jawa Tengah \\ hartatililik91@gmail.com
}

\author{
$2^{\text {nd }}$ Sri Wahyuni \\ Program Studi DIII Kebidanan \\ Sekolah Tinggi Ilmu Kesehatan \\ Muhammadiyah Klaten \\ Jl. Ir. Soekarno Km.1, Buntalan, Klaten \\ Tengah, Klaten, Jawa Tengah \\ hartatililik91@gmail.com
}

\author{
$3^{\text {rd }}$ Anna Uswatun Qoyyimah \\ Program Studi DIII Kebidanan \\ Sekolah Tinggi Ilmu Kesehatan \\ Muhammadiyah Klaten \\ J1. Ir. Soekarno Km.1, Buntalan, Klaten \\ Tengah, Klaten, Jawa Tengah \\ hartatililik91@gmail.com
}

Abstract-Sexually Transmitted Infections (STIs) are various infections that can be transmitted from one person to another through sexual contact. It can inhibit the meeting of the egg and sperm, resulting in infertility. This scarring also increases the risk of ectopic pregnancy or pregnancy in the fallopian tubes. The purpose of this research is to find out whether sexual behavior causes complaints on sexually transmitted infections in the work area of the Community Health Center of Pedan. The method used in this research is analytical descriptive method with retrospective approach. The population of this research is $\mathbf{4 0}$ female sex workers in the work area of the Community Health Center of Pedan. Samples are collected using Non-probability technique, that is total sampling. Data is analyzed using chi square test. The results showed there is a correlation between sexual behavior and the incidence of sexually transmitted infections in female sex workers in the work area of the Community Health Center of Pedan, with $p$ value of $0.001(p \leq 0.05)$. The conclusion is sexual behavior cause complaints on sexually transmitted infections in female sexual workers.

Keywords - sexual behavior, incidence of sexually transmitted infections

\section{INTRODUCTION}

Sexually Transmitted Infections (STIs) are various infections that can be transmitted from one person to another through sexual contact. STIs commonly found in Indonesia are Gonorrhea and syphilis. One of the diseases of STIs that cannot be cured is HIV/AIDS. HIV/AIDS are caused by free sex, decline in religious values, lifestyle, work, and failure to foster households. STIs cause reproductive tract infections that must be paid attention seriously [1]. Someone with STI who has not handled properly will experience scarring in the fallopian tubes. It can inhibit the meeting of the egg and sperm, resulting in infertility. This scarring also increases the risk of ectopic pregnancy or pregnancy in the fallopian tubes. Ectopic pregnancy is potentially life threatening [2]. Sexually transmitted infections are inseparable from the factors that influence it. Those factors are demographic changes, attitudes and behavior changes due to the demographic factors especially in the field of religion and morals, provision of health education especially genetic health, the use of antibiotic drugs without a doctor's prescription that causes germ resistance to antibiotics, health care facilities. Moreover, there are many cases of asymptomatic STI, where the patients do not feel sick but infect their sexual partners [3]. The results of interview with 10 female sex workers show that 4 sexual worker feel pain when urinating and leucorrhoea or yellowish and smelly vaginal discharge. Motivation for having free sex is to get money and can help them find peace. Moreover, 4 female sex workers state that they do not use condoms during free sex. Based on the preliminary study, it is concluded that female sex workers have not considered sexual behavior with complaints on Sexually Transmitted Infections (STIs)important. They do not understand how to overcome the pain of Sexually Transmitted Infections (STIs) and do not know how to stop doing free sex.

\section{METHOD}

This study uses a descriptive-analytic research design with a retrospective time approach. Population in this study is 40 female sex workers. Samples used in this study are 40 commercial sex workers in Krendengan village in Pedan district. Data was collected using sexual behavior questionnaire for female sex workers. Data was analyzed using chi square to determine the correlation between sexual behavior and the incidence of sexually transmitted infections. 


\section{RESULT}

\section{A. Bivariate Analysis}

TABLE I. THE CORRELATION BETWEEN SEXUAL BEHAVIOR AND COMPLAINTS ON SEXUALLY TRANSMITTED INFECTIONS (STIS) IN FEMALE SEX WORKERS THE WORK AREA OF THE COMMUNITY HEALTH CENTER OF PEDAN.

\begin{tabular}{|c|c|c|c|c|c|c|c|}
\hline \multirow{3}{*}{$\begin{array}{c}\text { Sexual } \\
\text { behavior }\end{array}$} & \multicolumn{4}{|c|}{ Incidence of STIs } & \multirow{3}{*}{ Total } & \multirow{3}{*}{ value } & \multirow{3}{*}{$\mathbf{P}$} \\
\hline & \multicolumn{2}{|c|}{$\begin{array}{c}\text { Complaints } \\
\text { on STIs }\end{array}$} & \multicolumn{2}{|c|}{$\begin{array}{c}\text { No } \\
\text { complaints } \\
\text { on STIs }\end{array}$} & & & \\
\hline & $\mathrm{F}$ & $\%$ & $\mathrm{~F}$ & $\%$ & & & \\
\hline Safe & 2 & 5.0 & 3 & 7.5 & 5 & & \\
\hline Unsafe & 33 & 82.5 & 2 & 5.0 & 35 & 11.788 & 0.001 \\
\hline Total & 35 & 87.5 & 5 & 12.5 & 40 & & \\
\hline
\end{tabular}

Based on the analysis done using chi square, it is seen that there is a correlation between sexual behavior and complaints on Sexually Transmitted Infections (STIs) in female sex workers the work area of the Community Health Center of Pedan with $p$ value of $=0,001(\mathrm{p} \leq 0,05)$

\section{DISCUSSION}

A. The correlation between sexual behavior and complaints on Sexually Transmitted Infections (STIs) in female sex workers the work area of the Community Health Center of Pedan

Based on Table 1, it is known that the number of respondents who have safe sexual behavior with complaints on STIs is $2(5 \%)$ respondents while those who have no complaints on STI are 3 respondents. The number of respondents with unsafe sexual behavior with complaints on STIs is $33(82.5 \%)$ respondents and those with no complaints STI complaints $2(5 \%)$ respondents.

The cause of safe sexual behavior and complaints on STI is that they use condom when having sex, but suddenly the condom is leaking and the female sexual workers do not know that the condom is leaking and they do not know that their sexual partner has suffered from sexually transmitted infection, due to low education. There are respondents who have unsafe sexual behavior but do not have a sexually transmitted infection even though they do not use condoms. They often do health examination. In practice, many complaints in STIs are asymptomatic, making it difficult to eradicate and control the diseases. To be able to take maximum precautions, good data collection is also needed. This is needed to describe which areas are affected by STIs and are likely to have the risk of transmission [4].

Based on the results of the analysis using chi square test cross table, it is seen that there is a correlation between sexual behavior and complaints on Sexually Transmitted Infections (STIs) in female sex workers in the work area of the Community Health Center of Pedanwith a value of 11.788 and $p=0.001(p<0.05)$. Chi Square test shows that $p$ value $<0.05$ $(\alpha)$ which means Ho is rejected, indicating that there is a significant correlation. The $\mathrm{p}$ value between the variablesof Sexual Behavior and Complaints on Sexually Transmitted Infection is $0.001<0.05(\alpha)$ meaning that Ho is rejected and there is a significant correlation between Sexual Behavior and Complaints of Sexually Transmitted Infection in female sex workers in the work area of the Community Health Center of Pedan.
The results of this study are in line with a research done by [5] on risky sexual behavior and access to health services with the incidence of sexually transmitted infections. Based on the results of a statistical analysis, risky sexual behavior is related to the incidence of STIs in Papuan students at the BinterbusihASA Semarang Foundation $(p=0.001)$ and is a risk factor of the incidence of STIs happened to students. Risky sexual behavior has a 16-time risk of getting sexually transmitted infections compared to non-risky sexual behavior.

Based on other studies, it is seen that sexually transmitted infections (STIs) are diseases transmitted through sexual contact with clinical manifestations in the form of abnormalities, especially in the genitals. Failure of early detection of STIs can cause various complications such as pregnancy outside the womb, anogenital cancer, infection in newborns, or infection in pregnancy [6].

Practically, many STIs are asymptomatic, making it difficult to eradicate and to control this disease. To be able to take maximum precautions, good data collection is also needed. This is needed to describe which areas are affected by STIs and are likely to have the risk of transmission, to be localized further [7].

Knowledge about the impacts and consequences caused by unsafe sexual behavior will greatly affect the behavior of female sexual workers. Safe sexual behavior will certainly be a little more risky to a woman's reproductive health compared to unsafe sexual behavior. Another study conducted by [8] on the behavior of commercial sex workers towards the prevention of sexually transmitted diseases shows that this contagious disease is a disease occurred from sexual relations caused by a virus. Sexually transmitted diseases will be more at risk when having sexual intercourse with multiple partners through vaginal, oral, or anal sex [9].

Sexually transmitted diseases are diseases transmitted through sexual contact, where the outbreak of the disease is not merely on the genitals, but in various places outside the genitals.

\section{CONCLUSION}

There is a correlation between sexual behavior and the incidence of sexually transmitted infections in female sex workers in the the work area of the Community Health Center of Pedan, with $\mathrm{p}$ value of $0.001(\mathrm{p} \leq 0.05)$. The conclusion is sexual behavior cause complaints on sexually transmitted infections in female sex workers.

\section{REFERENCES}

[1] U. T. Kang M., Rochford A., Skinner S.R., Mindel A., Webb M., Peat J., "Sexual behaviour, sexually transmitted infections and attitudes to chlamydia testing among a unique national sample of young," BMC Public Health, pp. 1-7, 2014.

[2] C. Febiyantin and S. Kriswiharsi Kun, "Faktor-faktor yang berhubungan dengan kejadian infeksi menular seksual (IMS) pada wanita pekerja seksual (WPS) usia 20-24 Tahun di resosialisasi argorejo Semarang (Tesis)," Fak. Kesehat. Udinus, vol. 15, 2014.

[3] N. Genz, S. M. K. Meincke, M. L. V. Carret, A. C. L. Corrêa, and C. N. Alves, "Doenças sexualmente transmissíveis: Conhecimento e comportamento sexual de adolescentes," Texto e Context. Enferm., vol. 26, no. 2, pp. 1-12, 2017.

[4] S. Y. Huang, J. H. Hung, L. Y. Hu, M. W. Huang, S. C. Lee, and C. C. Shen, "Risk of sexually transmitted infections following depressive disorder: A nationwide population-based cohort study," Med. (United States), vol. 97, no. 43, pp. 1-7, 2018. 
[5] E. O. Amu and P. T. Adegun, "Awareness and Knowledge of Sexually Transmitted Infections among Secondary School Adolescents in Ado Ekiti, South Western Nigeria,” J. Sex. Transm. Dis., vol. 2015, pp. 17, 2015.

[6] F. Navarro-Cremades et al., "Sexual behaviour and risk of sexually transmitted infections in young female healthcare students in Spain," PeerJ, vol. 2016, no. 2, pp. 1-15, 2016.

[7] S. Bajaj et al., "Risk factors for sexually transmitted diseases in Canada and provincial variations," Soc. Med., vol. 11, no. 2, pp. 62-69, 2017.
[8] M. Gyawalee and D. Pokhrel, "Pattern Of Sexually Transmitted Infections And Sexual Behavior In Patients With Genital Symptoms," Nepal J. Dermatology, Venereol. Leprol., vol. 12, no. 1, pp. 20-27, 2016.

[9] S. A. F. Pract, "The treatment of sexually transmitted infections," South African Fam. Pract., vol. 58, no. 6, pp. 12-22, 2016. 